\title{
INFLUENCE OF STORAGE PERIOD ON OCCURRENCE AND DISTRIBUTION OF AFLATOXINS AND FUNGI IN MAIZE KERNELS
}

\author{
Jovana J. Kos ${ }^{* 1}$, Elizabet P. Janić Hajnal ${ }^{1}$, Ljubiša Ć. Šarić ${ }^{1}$, Dragana V. Plavšić1 ${ }^{1}$ Vojislava P. Bursić ${ }^{2}$, \\ Gorica Lj. Vuković ${ }^{3}$, Jasmina M. Lazarević ${ }^{1}$ \\ ${ }^{1}$ University of Novi Sad, Institute of Food Technology, 21000 Novi Sad, Bulevar cara Lazara 1, Serbia \\ ${ }^{2}$ University of Novi Sad, Faculty of Agronomy, 21000 Novi Sad, Trg Dositeja Obradovića 8, Serbia \\ ${ }^{3}$ University of Belgrade, Institute of Public Health, 11000 Belgrade, Bulevar despota Stefana 54a,
} Serbia

\author{
${ }^{*}$ Corresponding author: \\ Phone: +381214853837 \\ Fax: +38121450725 \\ E-mail address: jovana.kos@fins.uns.ac.rs
}

\begin{abstract}
This study had two major objectives: 1) to investigate the influence of a seven-month storage period on maize contamination with aflatoxins (AFs) and 2) to examine the distribution of total count of fungi (TCF), A. flavus and aflatoxin B1 (AFB1) in the stored maize kernels. In the first part of this survey, 700 maize samples were collected in the period from October 2012 to April 2013. Presence of AFs was detected in $72 \%$ of maize, before entering the silos. The survey results indicated that the percentage of contaminated maize samples as well as the distribution of determined AFs concentrations changed during the storage period of seven months. By the prolongation of storage period, the percentage of non-contaminated maize samples decreased from $28 \%$ to $16 \%$, while the percentage of contaminated samples in the concentration range $20-50 \mu \mathrm{g} / \mathrm{kg}$ increased from $18 \%$ to $25 \%$. In the second part of this study, 32 maize samples from four different silos were analysed. The results showed that TCF, A. flavus and AFB1 were unevenly distributed. According to Duncan's multiple range test, in each silo, statistically significant differences $(p<0.05)$ were noted for all tested parameters. Furthermore, within each silo, statistically significant correlation $(r=0.76$ at $p<0.05)$ between the number of $A$. flavus colonies and AFB1 concentrations were observed. According to the obtained results and taking into account the trends in climatic changes in Serbia, further improvement in maize management system concerning AFs is warranted. The findings of this study could be of great importance to increase the knowledge related to the AFs management strategies in Serbia as well as in neighboring countries.
\end{abstract}

Key words: maize kernels, storage, silo, aflatoxins; Aspergillus flavus, total count of fungi

\section{INTRODUCTION}

Maize (Zea mays L.) is an important cereal worldwide and one of the major crops grown in Serbia. Most of the total maize production in Serbia is mainly used for animal feed $(80 \%)$, while the rest is used for human consumption and starch production. Furthermore, in the recent years Serbia has been one of the largest maize producer and exporter in Europe as well as in the whole world (Maslac, 2013; Maslac, 2015).
One of the most frequent contaminants of maize is mycotoxigenic fungus Aspergillus (A.) flavus which can result in aflatoxins (AFs) production (Cotty and Mellon, 2006). AFs represent one of the most important mycotoxins group due to their prevalence and intensive toxic, mutagenic, teratogenic and carcinogenic effects, with proven acute and chronic toxicity in humans and animals (IARC, 2012). Among eighteen identified AFs, aflatoxin B1 (AFB1) is the most 
frequent one and potent liver carcinogen known in mammals. Besides AFB1, International Agency for Research on Cancer (IARC) defined AFB2, AFG1, and AFG2 as primary carcinogenic compounds (IARC, 2012). A. flavus is a very common and widespread fungus in nature which grows and produces AFs during different phases of maize growth, harvest, processsing, transportation and storage (Ellis et al., 1991). Since maize as starch-based material represents a good substrate for aflatoxigenic fungi, the most influential factors affecting the occurrence of $A$. flavus and the amount of AFs in maize are environmental and storage conditions. The influence of environmental conditions on the production of AFs during maize growing season was reported in many studies (Abbas et al., 2002; Juan et al., 2008; Kos et al., 2013). In recent study, KaramiOsboo et al. (2012) highlighted drought as the main factor affecting the production of AFs in maize. Furthermore, agronomic factors (type of hybrid, soil, tillage, previous crop), postharvest management, inappropriate storage conditions (temperature, humidity, handling, presence of insects, rodents and birds) as well as extended storage period may influence on increasing risk of $A$. flavus and AFs presence in stored maize (Hell et al., 2000; Garrido et al., 2012). Some authors reported that contamination with $A$. flavus and subsequent production of AFs during storage is considered as one of the most serious safety problems throughout the world. In addition, it is known that AFs are stable compounds that cannot be destroyed during most of the maize processing operations, therefore improvements in agricultural practices, in particular grain production and storage environments is required (Williams et al., 2004).

Until 2012, occurrence of AFs in maize was not considered a typical agricultural issue in Serbia (Matić et al., 2009; Kokić et al., 2009). However, weather condition changes during maize growing season in 2012 resulted in AFs outbreak in maize kernels. Our previous investigation showed that prolonged drought influenced AFs presence in 137 (68.5\%) maize samples among total 200 samples analysed
(Kos et al., 2013). Furthermore, presence of AFs in maize resulted in toxin presence in feedstuffs (Lević et al., 2013a) as well as in food of animal origin, especially in milk (Kos et al., 2014). Occurrence of AFs in Serbia during 2012/2013 period caused "aflatoxins crisis" followed with numerous protests of agricultural workers and milk producers in the street, several changes of Regulations regarding maximum level (ML) and significant economic losses for processors, producers and marketers (Torović, 2015). It was assumed that the "aflatoxin crisis" during 2012/2013 could have cost Serbia between 100 and 125 million euros (Radović and Keković, 2014).

Even though the presence of AFs in 20122013 maize had led to huge economic losses, available official data as well as the national database on AFs occurrence have still been insufficient. Furthermore, significant changes in climatic conditions during previous years in Serbia require further investigations especially in relation to improvement in maize management system concerning the presence of $A$. flavus and AFs.

Therefore, the first objective of this study was to examine the effect of storage period (seven months) on AFs contamination of maize kernels and the second objective was to investigate the distribution of total count of fungi (TCF), A. flavus and AFB1 in the stored maize.

\section{MATERIAL AND METHODS}

\section{Samples, kits and chemicals}

For the first part of investigation, seven hundred $(n=700)$ maize kernel samples were collected. Every month, in the period from October 2012 to April 2013, 100 maize samples were collected, transported to the laboratory and analyzed. Only in October 2012, 100 samples were analyzed immediately after harvest without previous storage. The samples were taken from different silos which were representative in size, composition and storage method applied. It means that during the storage period there was a constant effort to minimize any possibility of maize quality reduction caused by changes in storage conditions (temperature and humidity), as 
well as mechanical damage influenced by insects, rodents and birds.

In order to examine the distribution of TCF, A. flavus and AFB1 concentration, thirty two $(n=32)$ maize samples from four silos were included in the second part of investigation. Storage capacity of silos was around $800 \mathrm{t}$. The sampling was performed during the elevation procedure from eight different sections of each silo.

With the aim to provide the representative maize samples for the first and the second part of investigations, sampling procedure was performed according to the European Union (EU) requirements (European Commission Regulation, 2006a). Aggregate samples of approximately 5-10 kg were composed of different number of incremental samples. These samples were homogenized and quartered to obtain a 500 $\mathrm{g}$ of laboratory samples which were kept in freezer at $-18{ }^{\circ} \mathrm{C}$ until the analysis. The obtained representative samples were ground to $1 \mathrm{~mm}$ particle size using a laboratory mill (KnifetecTM 1095 mill, Foss, Hoganas, Sweden).

\section{Aflatoxins analysis}

Due to high number of analysed samples $(n=700)$, samples from the first part of this study were analyzed using validated Enzyme Linked Immunosorbent Assay (ELISA) method, while 32 samples from the second part were analyzed using High Performance Liquid Chromatography with Fluorescence Detector (HPLC-FLD).

\section{ELISA method}

Determination of AFs (AFB1, AFB2, AFG1 and $A F G 2$ ) in 700 maize samples was performed by ELISA method using two test kits produced by Neogen Corporation (Quantitative AFs HS Test kit and AFs Quantitative Test kit, Neogen Veratox®, Lansing, USA). Chemicals used for ELISA method were distilled water (Millipore, BedFord, MA, USA) and methanol of analytical purity (Merck, Darmstad, Germany). Subsamples of $5 \mathrm{~g}$ were extracted with 25 $\mathrm{ml}$ of methanol:water mixture $(70: 30, \mathrm{v} / \mathrm{v})$ and shaken vigorously for three minutes on laboratory Griffin flask shaker (Griffin and George, Wembley, England). Extracts were filtered through the Whatman No. 1 filter paper (Whatman International Ltd.,
Maidstone, UK). The instructions given by the manufacturer for AFs determination were strictly followed.

\section{HPLC-FLD method}

HPLC-FLD method was applied for the analysis of AFB1 in 32 maize samples from the second part of investigation. For HPLC analysis acetonitrile, methanol, nhexane and trifluoroacetic acid (TFA) were purchased from Merck (Darmstadt, Germany). Used water was ultrapure (Milli-Q from Millipore, USA). Aflatoxin B1 standard with certificated concentration of 2 $\mu \mathrm{g} / \mathrm{ml}$ was purchased from Sigma Aldrich (Prague, Czech Republic). Twenty-five grams of maize samples were extracted with $100 \mathrm{ml}$ acetonitrile:water (84:16, v/v) and shaken vigorously for thirty minutes using laboratory Griffin flask shaker (Griffin and George, Wembley, England). After extraction, extract was filtered through filter paper (Whatman No. 4, Maidstone, UK) and $5 \mathrm{ml}$ of filtered extract was cleaned up with Mycosep $® 224$ AflaZon multifunctional columns (Romer Labs. Inc., Union, MO, USA). The purified extract was then evaporated to dryness (Reacti Term, Thermo Fisher, Scientific Bellefonte, P. A. USA). Due to the poor fluorescence of AFB1, post derivatization step for enhancing its fluorescence on HPLC-FLD was required. Derivatization was achieved by adding $100 \mu \mathrm{l}$ of TFA and $200 \mu \mathrm{l}$ of $n$ hexane to sample extracts or AFB1 working standards. This mixture was vortexed for $30 \mathrm{~s}$ and kept in the dark at $40{ }^{\circ} \mathrm{C}$ for $10 \mathrm{~min}$. After evaporation, $400 \mu \mathrm{l}$ of acetonitrile:water $(1: 9, \mathrm{v} / \mathrm{v})$ mixture was added to the vials and vortexed again for $30 \mathrm{~s}$. The HPLC instrument was an Agilent 1200 system equipped with a fluorescence detector (FLD), a binary pump, a vacuum degasser, an autosampler and Agilent column (Eclipse XDB-C18, $1.8 \mu \mathrm{m}, 4.6 \mathrm{x}$ $50 \mathrm{~mm}$ ). The AFB1 analysis was performed with a mobile phase consisted of $65 \%$ of water and $35 \%$ of a mixture of acetonitrile:methanol $(50: 50, \mathrm{v} / \mathrm{v})$ with a flow rate of $0.2 \mathrm{ml} / \mathrm{min}$. Ten microliters of standards or samples were injected into the HPLC column. The fluorescence detector was set to an excitation and emission wavelengths of $365 \mathrm{~nm}$ and $440 \mathrm{~nm}$, respectively. 


\section{Mycological survey}

Analyses of TCF in maize kernel samples were performed according to ISO standard (ISO, 21527-2, 2008). Colonies that were assumed to belong to Aspergillus species were transferred on Czapek Yeast Extract Agar (CYA).

Seeded surfaces were incubated during the period of 7 days at $25^{\circ} \mathrm{C}$. The criteria described by Samson et al. (2004) and Pitt and Hocking (2009) were applied for species identification. Taxonomic classifycation was determined on the basis of macromorphological and micromorphological characteristics of growing colonies.

\section{Quality control}

Analyses of all maize kernel samples were carried out in accredited laboratory of the Institute of Food Technology, University of Novi Sad. The laboratory was accredited in agreement with standard SCS ISO/IEC 17025 (2006).

The analytical quality of the applied ELISA and HPLC-FLD methods were assured by the use of certified reference material (CRM). Naturally contaminated maize sample (Progetto Trieste, Test Veritas, Padova Italy) with certified AFB1 $(4.98 \pm 3.54 \mu \mathrm{g} / \mathrm{kg})$ and AFs $(6.46 \pm 4.42$ $\mu \mathrm{g} / \mathrm{kg}$ ) content was used as the CRM. The validation parameters were calculated and expressed using European Official Decision procedure (European Commission Regulation, 2002).

\section{Statistical analysis}

Statistical analysis of variance was carried out by Duncan's multiple comparison tests using STATISTICA software version 10 (StatSoft Inc. 2011, USA). P values $<0.05$ were regarded as significant.

\section{RESULTS AND DISCUSSION}

The results of the validation methodology are shown in Table 1. The validation parameters, for both used ELISA test kits as well as HPLC-FLD method, were in compliance with recommendations given in the Regulation 2006/401/EC (European Commission Regulation, 2006a).

Seven hundred maize kernel samples were analyzed with the aim to investigate influence of storage period of seven months on AFs contamination. The obtained results for each month in the period from October 2012 to April 2013 are summarized and shown in Fig. 1. Determined AFs concentrations were distributed in the following five concentrations ranges: $<1 \mu \mathrm{g} / \mathrm{kg}, 1 \mu \mathrm{g} / \mathrm{kg}-10 \mu \mathrm{g} / \mathrm{kg}, 10 \mu \mathrm{g} / \mathrm{kg}-20$ $\mu \mathrm{g} / \mathrm{kg}, 20 \mu \mathrm{g} / \mathrm{kg}-50 \mu \mathrm{g} / \mathrm{kg}$ and $>50 \mu \mathrm{g} / \mathrm{kg}$. As it can be seen from Fig. 1. significant variation in the distribution of AFs concentrations within investigated months were noticed. The greatest percentage $(28 \%)$ of maize kernel samples that were not contaminated with AFs (c $<1 \mu \mathrm{g} / \mathrm{kg}$ ) was noted in maize samples collected in October 2012. The possible reason for that is the fact that only maize samples from October were analyzed immediately after harvest without previous storage. On the other hand, in the maize samples which were stored and collected from the silos, the percentage of non-contaminated maize samples decreased (from $26 \%$ in November to $16 \%$ in March) with the prolongation of storage period.

Table 1.

Validation parameters for ELISA and HPLC-FLD methods

\begin{tabular}{|c|c|c|c|}
\hline \multirow{4}{*}{$\begin{array}{l}\text { Determined } \\
\text { parameters }\end{array}$} & \multicolumn{3}{|c|}{ Method } \\
\hline & \multicolumn{2}{|c|}{ ELISA } & \multirow{2}{*}{ HPLC-FLD } \\
\hline & Quantitative HS Test & Quantitative Test & \\
\hline & \multicolumn{2}{|l|}{ AFs } & AFB1 \\
\hline LOD & 0.50 & 1.00 & 0.30 \\
\hline LOQ & 1.00 & 5.00 & 1.00 \\
\hline $\mathrm{RSD}_{\mathrm{r}}$ & 4.86 & 8.12 & 7.31 \\
\hline $\mathrm{RSD}_{\mathrm{R}}$ & 6.12 & 11.1 & 10.5 \\
\hline Recovery & 103.2 & 96.1 & 98.2 \\
\hline
\end{tabular}

LOD: limit of detection $(\mu \mathrm{g} / \mathrm{kg})$

LOQ: limit of quantification $(\mu \mathrm{g} / \mathrm{kg})$

$R S D_{r}$ : relative standard deviation calculated under repeatability conditions (\%)

$R S D_{R}$ : relative standard deviation calculated under reproducibility conditions (\%)

Recovery: (\%) 


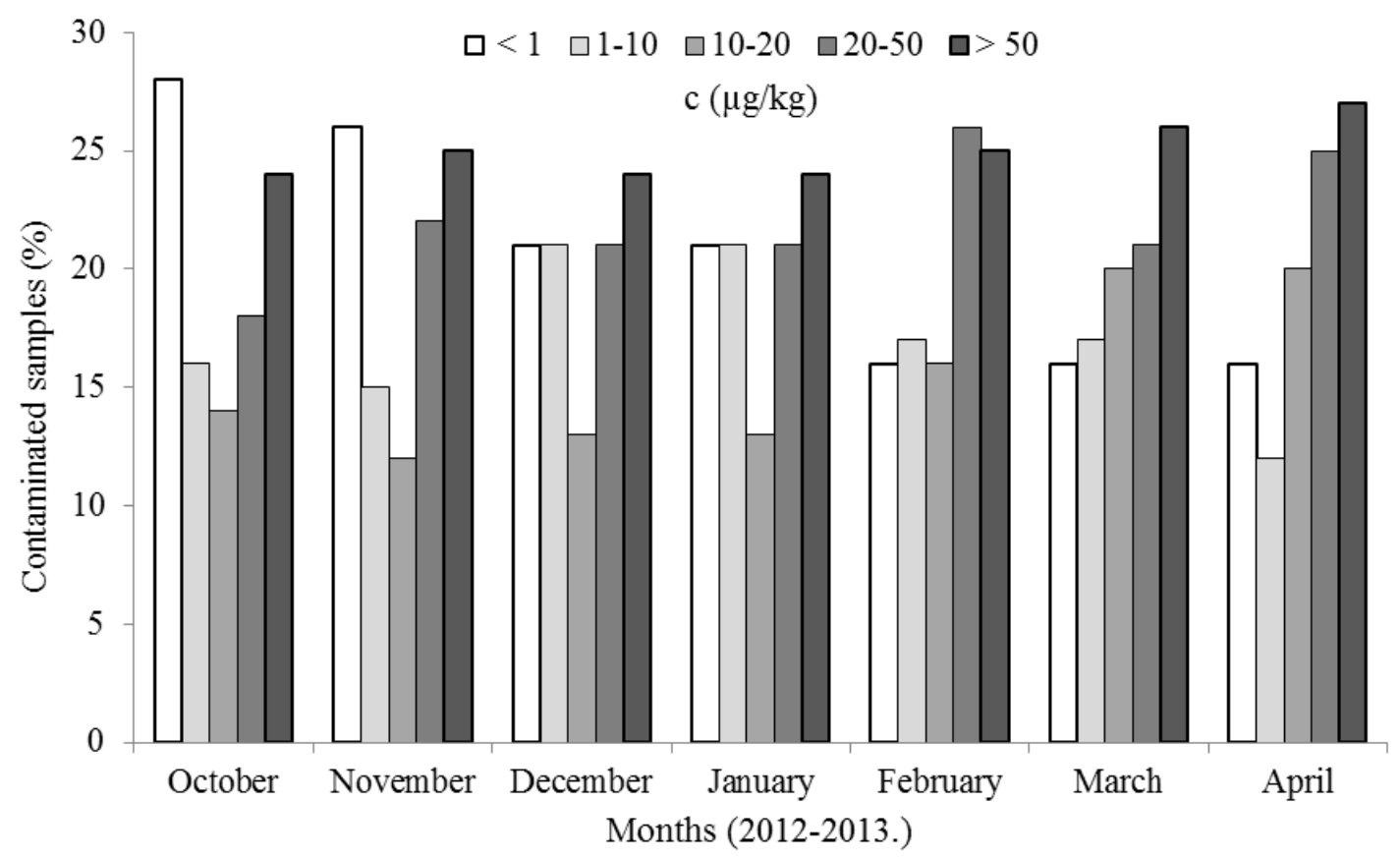

Figure 1. Percentage of contaminated maize samples and distribution of AFs concentrations during the storage period of seven months

During the last three months of storage (February, March and April 2013), the percentage of non-contaminated maize samples was not changed significantly and it was around $16 \%$. Furthermore, by the prolongation of storage period, the percentage of contaminated samples in the concentration range from $1 \mu \mathrm{g} / \mathrm{kg}$ to $10 \mu \mathrm{g} / \mathrm{kg}$ was variable. It means that from October 2012 to January 2013, the percentage of contaminated samples in the range 1-10 $\mu \mathrm{g} / \mathrm{kg}$ increased from $16 \%$ to $21 \%$, while from February to April 2013, it decreased from $17 \%$ to $12 \%$. Simultaneously with the decrease in percentage of samples contaminated in the range $1-10 \mu \mathrm{g} / \mathrm{kg}$, an increase of contaminated samples in the range $10-20 \mu \mathrm{g} / \mathrm{kg}$ from $14 \%$ to $20 \%$ was noticed. The most pronounced changes were observed in the concentration range from $20 \mu \mathrm{g} / \mathrm{kg}$ to $50 \mu \mathrm{g} / \mathrm{kg}$. During the investigated period of seven months, the prevalence of contaminated samples in this concentration range increased from $18 \%$ to $25 \%$. Furthermore, the percentage of contaminated samples with AFs concentration over $50 \mu \mathrm{g} / \mathrm{kg}$ did not significantly vary (from $23 \%$ to $27 \%$ ) during the 7-month storage period. Based on the obtained results, it could be noted that the percentage of contaminated maize kernel samples as well as the distribution of AFs concentration were changed during the storage time period of seven months.

Changes in AFs concentrations over the investigated 7-month period also influenced the relative proportion of samples which were suitable for human and animal nutrition. For example, $44 \%$ of maize samples from October 2012 contained AFs in concentration lower than $10 \mu \mathrm{g} / \mathrm{kg}$. This level of AFs concentration corresponds to the maximum level (ML) for AFs (sum of AFB1, AFB2, AFG1 and AFG2) in food intended for human consumption according to national legislative (Pravilnik, 2011) and EU Regulation (European Commission Regulation, 2006b).

Contrary to this, in the last month of storage (April 2013), only $28 \%$ of maize samples was suitable for human diet. In addition, the Serbian Regulation (Pravilnik, 2010) in force at the time of examination of maize samples, set $50 \mu \mathrm{g} / \mathrm{kg}$ as $\mathrm{ML}$ for AFs in maize intended for animal consumption. Based on this criteria, between $24 \%$ and $27 \%$ of maize samples was unsuitable for this purpose. However, the EU Regulation (European Commission Regulation, 2002) set stricter limits and only samples with AFB1 concentration 
less than $20 \mu \mathrm{g} / \mathrm{kg}$ can be used in animal diet. During 2013, relevant Serbian authorities changed the national Regulation and previous $\mathrm{ML}$ of $50 \mu \mathrm{g} / \mathrm{kg}$ for AFs was lowered to $30 \mu \mathrm{g} / \mathrm{kg}$ for AFB1 in maize intended for animal feed (Pravilnik, 2013). Complete harmonization of Serbian Regulation with EU rules regarding the presence of AFB1 in maize as well for AFM1 in milk has been still missing which indicates that the "aflatoxin crisis" continues its presence in the country. Since Serbia represents a candidate for EU membership, complete harmonization of regulations is required in future.

Results from our previous study (Kos et al., 2013) indicated that prolonged drought, characterized with high temperatures and small amount of precipitation was recognized as the main factor which influenced the outbreak of AFs in maize during the 2012 growing season. The described weather conditions were favourable for some Aspergillus species, in particular A. flavus, which can grow and synthesise AFs in drought conditions (Santin, 2005). However, in previous years in Serbia, due to unfavourable weather conditions, presence of AFs was not detected in maize kernels as well as in other grain materials (Matić et al., 2009; Kokić et al., 2009; Kos et al., 2013). The general absence of AFs in agricultural commodities from Serbia in previous years could be one of the possible reasons for the lack of knowledge and experience concerning the management of contaminated material. In this regard, after the harvest in October 2012, maize contaminated with AFs was mainly stored in silos without any applied physical or chemical procedure for reduction of AFs concentration. Therefore, from October 2012 to April 2013, Aspergillus species continued with their growth and AFs synthesis that resulted in changes of percentage of contaminated maize samples as well as distribution of AFs concentrations during the storage period of seven months. To the best of authors' knowledge, there are none published data in the literature related to the investigated topics in Serbia as well as in the neighbourring countries. Furthermore, only several published studies from South America and Africa dealt with evaluation of the effect of storage period on changes of AFs concentration in maize. Hell et al. (2000) and Kaaya et al. (2006) reported that AFs contamination increased during period of maize storage. Hell et al. (2000) investigated the influence of six month-storage period on AFs contamination of maize samples from four agroecological zones of Benin in West Africa. The authors reported that percentage of contaminated samples (c > $5 \mu \mathrm{g} / \mathrm{kg}$ ) in four different zones before storage varied from $9.9 \%$ to $32 \%$, while after period of six months, percentage of non-contaminated samples decreased. Furthermore, prevalence of maize samples contaminated with AFs at concentrations over $100 \mu \mathrm{g} / \mathrm{kg}$ varied between 2.2 $\%$ and $5.8 \%$ at the beginning of storage and between $7.5 \%$ and $24 \%$ after period of six months. As it can be seen, initial AFs contamination $(9.9 \%$ to $32 \%)$ in the study from Benin was significantly lower in comparison to the initial AFs contamination $(72 \%)$ observed in this survey. Kaaya et al. (2006) reported that maize samples stored in Uganda for more than six months were contaminated with higher concentration of AFs in comparison to the maize samples stored in a period from two to six months. It should be emphasized, that storage facilities in Benin as well as in Uganda are significantly different in comparison to storage facilities in Serbia, which were included in this study. Therefore, complete comparison of obtained results is difficult. Similarly, Keller et al. (2013) concluded that prolongation of storage period had a great influence on the increase of AFs contamination in stored maize silage. In the second part of this study, a total of 32 maize samples were collected from four different silos with the aim to investigate distribution of TCF, $A$. flavus and AFB1 in stored maize kernels. As it can be seen from Table 2, the obtained results indicated significant differences in the distribution of investigated parameters within each silo. In regard to TCF, it could be noticed that in the examined maize samples, TCF varied from 85.0 to $230 \mathrm{cfu} / \mathrm{g} \times 10^{3} \mathrm{cfu} / \mathrm{g}, 105$ to 320 $\mathrm{cfu} / \mathrm{g} \times 10^{3} \mathrm{cfu} / \mathrm{g}, 90.0$ to $320 \mathrm{cfu} / \mathrm{g} \times 10^{3}$ cfu/g and 50.0 to $550 \times 10^{3} \mathrm{cfu} / \mathrm{g}$ in the first, second, third and fourth silo, respectively. 
Table 2.

Fungal mycobiota and aflatoxin B1 contamination of maize samples collected from four silos

\begin{tabular}{|c|c|c|c|c|c|c|c|c|c|c|}
\hline \multicolumn{11}{|c|}{ Silo 1} \\
\hline & \multicolumn{8}{|c|}{ No } & \multirow{2}{*}{ Average $\pm S D$} & \multirow{2}{*}{ Min-Max } \\
\hline & 1 & 2 & 3 & 4 & 5 & 6 & 7 & 8 & & \\
\hline & $85^{\mathrm{C}}$ & $215^{\dagger}$ & $230^{b}$ & $190^{e}$ & $156^{a}$ & $230^{b}$ & $160^{a}$ & $135^{\mathrm{d}}$ & $175 \pm 50.9$ & $85.0-230$ \\
\hline A.flavus & $6.50^{\mathrm{a}}$ & $7.50^{\mathrm{ab}}$ & $8.50^{b}$ & $6.20^{a}$ & $12.5^{\mathrm{c}}$ & $57.5^{\dagger}$ & $32.0^{\mathrm{e}}$ & $15.0^{d}$ & $18.2 \pm 18.0$ & $6.20-57.5$ \\
\hline$c(A F B 1)$ & $35.9^{e}$ & $37.2^{\dagger}$ & $11.6^{b}$ & $28.4^{c}$ & $10.4^{a}$ & $33.4^{\mathrm{d}}$ & $88.1^{\mathrm{h}}$ & $40.8^{g}$ & $35.7 \pm 24.1$ & 10.4-88.1 \\
\hline \multicolumn{11}{|c|}{$\begin{array}{l}\text { Silo } 2 \\
\end{array}$} \\
\hline & \multicolumn{8}{|c|}{ No } & \multirow{2}{*}{ Average $\pm S D$} & \multirow{2}{*}{ Min-Max } \\
\hline & 1 & 2 & 3 & 4 & 5 & 6 & 7 & 8 & & \\
\hline TCF & $155^{\mathrm{C}}$ & $190^{\mathrm{e}}$ & $320^{9}$ & $165^{\mathrm{d}}$ & $105^{b}$ & $230^{\dagger}$ & $205^{a}$ & $210^{a}$ & $197 \pm 63.0$ & $105-320$ \\
\hline A.flavus & $6.10^{c}$ & $11.5^{\mathrm{a}}$ & $16.0^{\mathrm{b}}$ & $10.0^{a}$ & $12.7^{\mathrm{ab}}$ & $30.0^{d}$ & $12.5^{\mathrm{ab}}$ & $105^{e}$ & $25.5 \pm 32.9$ & $6.10-105$ \\
\hline$c(A F B 1)$ & $<1^{\mathrm{a}}$ & $20.9^{c}$ & $57.9^{\dagger}$ & $<1^{a}$ & $31.9^{d}$ & $45.1^{\mathrm{e}}$ & $16.5^{\mathrm{b}}$ & $183^{g}$ & $59.3 \pm 62.6$ & $16.5-183$ \\
\hline \multicolumn{11}{|c|}{ Silo 3} \\
\hline & \multicolumn{8}{|c|}{ No } & \multirow{2}{*}{ Average $\pm S D$} & \multirow{2}{*}{ Min-Max } \\
\hline & 1 & 2 & 3 & 4 & 5 & 6 & 7 & 8 & & \\
\hline TCF & $320^{9}$ & $160^{\mathrm{d}}$ & $200^{e}$ & $260^{\dagger}$ & $120^{\mathrm{a}}$ & $130^{c}$ & $90.0^{D}$ & $120^{a}$ & $175 \pm 79.6$ & $90.0-320$ \\
\hline A.flavus & $40.0^{\dagger}$ & $8.00^{a}$ & $30.0^{\mathrm{e}}$ & $22.0^{C}$ & $20.0^{b c}$ & $10.0^{d}$ & $7.00^{a}$ & $20.0^{\mathrm{b}}$ & $19.6 \pm 11.4$ & $7.00-40.0$ \\
\hline c (AFB1) & $71.9^{h}$ & $39.9^{e}$ & $53.1^{\mathrm{g}}$ & $24.4^{c}$ & $37.1^{d}$ & $23.0^{b}$ & $9.50^{\mathrm{a}}$ & $51.6^{f}$ & $38.8 \pm 19.9$ & $9.50-71.9$ \\
\hline \multicolumn{11}{|c|}{ Silo 4} \\
\hline & \multicolumn{8}{|c|}{ No } & \multirow{2}{*}{ Average $\pm S D$} & \multirow{2}{*}{ Min-Max } \\
\hline & 1 & 2 & 3 & 4 & 5 & 6 & 7 & 8 & & \\
\hline TCF & $550^{9}$ & $350^{\dagger}$ & $110^{a}$ & $50.0^{b}$ & $110^{a}$ & $140^{\mathrm{d}}$ & $170^{e}$ & $80.0^{c}$ & $195 \pm 170$ & $50.0-550$ \\
\hline A.flavus & $30.0^{C}$ & $40.0^{d}$ & $20.0^{\mathrm{b}}$ & $10.0^{\mathrm{a}}$ & $50.0^{\mathrm{e}}$ & $18.0^{\mathrm{b}}$ & $10.0^{\mathrm{e}}$ & $33.0^{\mathrm{C}}$ & $26.4 \pm 14.4$ & $10.0-50.0$ \\
\hline $\mathrm{c}(\mathrm{AFB} 1)$ & $9.70^{\mathrm{b}}$ & $100^{9}$ & $59.6^{\mathrm{e}}$ & $<1^{\mathrm{a}}$ & $75.2^{\dagger}$ & $49.1^{c}$ & $54.3^{\mathrm{d}}$ & $150^{\mathrm{h}}$ & $71.2 \pm 44.4$ & $9.70-150$ \\
\hline \multirow{2}{*}{\multicolumn{11}{|c|}{$\begin{array}{l}a, b, c, d, e, t, g, h \text { Values indicated with different letters are significantly different according to Duncan's multiple rang } \\
\text { test }(p<0.05) \text {. Differences were analyzed separately for every parameter (TCF, A. flavus and AFB1) in each silo. }\end{array}$}} \\
\hline & & & & & & & & & & \\
\hline \multicolumn{11}{|c|}{$\begin{array}{l}\text { No: sample number } \\
\text { TCF: total count of fungi }\end{array}$} \\
\hline \multicolumn{11}{|c|}{$\begin{array}{l}\text { TCF: total count of fungi } \\
\text { TCF and } A . \text { flavus: }\left(\times 10^{3} \mathrm{cfu} / \mathrm{g}\right)\end{array}$} \\
\hline \multicolumn{11}{|c|}{$c(A F B 1): \mu g / k g$} \\
\hline \multicolumn{11}{|c|}{$\begin{array}{l}\text { Average } \pm S D: \text { average concentration }(\mu g / k g) \pm \text { standard deviation }(\mu g / k g) \\
\text { Min-Max: minimum and maximum concentrations }(\mu q / \mathrm{kg})\end{array}$} \\
\hline Min-Max: $n$ & & & & & & & & & & \\
\hline
\end{tabular}

Significant differences in terms of TCF were noted within each silo, which means that mycobiota were very unevenly distributed. The currently valid Serbian Regulation for microbiological criteria for food (Pravilnik, 2010), does not define the maximum TCF in maize. However, earlier edition of this Regulation (Pravilnik, 1993) defined $10 \times 10^{3} \mathrm{cfu} / \mathrm{g}$ as maximum TCF allowed in maize kernels. In all 32 analyzed maize samples, TCF was greater than $10 \times 10^{3} \mathrm{cfu} / \mathrm{g}$. A. flavus was present in all of 32 analyzed maize samples with significant individual variations within each silo. Minimum and maximum counts of $A$. flavus colonies were distributed in the following way: $6.20-57.5 \times 10^{3} \mathrm{cfu} / \mathrm{g}$ in the first silo, $6.10-105 \times 10^{3} \mathrm{cfu} / \mathrm{g}$ in the second, $7.00-40.0 \times 10^{3} \mathrm{cfu} / \mathrm{g}$ in the third, and 10.0-50.0 $\times 10^{3} \mathrm{cfu} / \mathrm{g}$ in the fourth silo. Among 32 analyzed maize samples, AFB1 was not detected in only two samples from the second and one sample from the fourth silo. Moreover, the AFB1 concentrations within each silo were very differ- rent. The AFB1 concentration ranges were: 10.4 - $88.1 \mu \mathrm{g} / \mathrm{kg}, 16.5$ - $183.0 \mu \mathrm{g} / \mathrm{kg}$, $9.50-71.9 \mu \mathrm{g} / \mathrm{kg}$ and $9.70-150.0 \mu \mathrm{g} / \mathrm{kg}$ for the first, second, third and fourth silo, respectively. The total count of fungi, $A$. flavus and AFB1 were unevenly distributed in the examined silos and according to Duncan's multiple range test $(P<0.05)$ statistically significant differences were noted for each of the examined parameter (TCF, A. flavus and AFB1) in every silo. The largest contamination range was noted in the second silo: the sample contamination with AFB1 and $A$. flavus spanned from $16.5 \mu \mathrm{g} / \mathrm{kg}$ to $183 \mu \mathrm{g} / \mathrm{kg}$ and from 6.10 to $105 \mathrm{cfu} / \mathrm{g} \times 10^{3} \mathrm{cfu} / \mathrm{g}$, respectively. Furthermore, in the same silo, among eight samples, only two were not contaminated with AFB1 at concentration over 1 $\mu \mathrm{g} / \mathrm{kg}$.

The largest number of determined $A$. flavus colonies (105 cfu/g x $10^{3} \mathrm{cfu} / \mathrm{g}$ ) caused the highest determined AFB1 concentration $(183 \mu \mathrm{g} / \mathrm{kg}$ ) (Silo 2, sample 8). Furthermore, it could be noticed that the 
smallest number of $A$. flavus colonies $\left(6.10 \mathrm{cfu} / \mathrm{g} \times 10^{3} \mathrm{cfu} / \mathrm{g}\right)$ was determined in the sample with AFB1 concentration below $1 \mu \mathrm{g} / \mathrm{kg}$ (Silos 2, sample 1). However, correlation may not be so straightforward as the presence of $A$. flavus colonies in large number does not necessary mean the presence of the high concentrations of AFB1 as well as that the lower number of $A$. flavus colonies does not necessary mean the absence of AFB1. This is in accordance with the study reported by Harley et al. (1997) which indicated that mycotoxins content is not always related to the amount of fungi present. However, the results from our study showed statistically significant correlation $(r=0.76$ at $p<0.05)$ between the number of $A$. flavus colonies and AFB1 concentrations observed in each of the four silos. Some authors also confirmed heterogeneous distribution of $A$. flavus and AFB1 as well as occurrence of AFB1 in pockets with different concentrations in stored contaminated maize (Trung et al., 2008; Luftullah and Hussain, 2012).

Castellari et al. (2010) reported that Aspergillus species represent one of the most common fungal genera identified in stored maize. The proliferation of these fungi as well as AFs biosynthesis may be stimulated by the following factors: moisture content, high temperature during storage, long storage period, and intensive infection by fungi before storage and by higher activity of insects, rodents and birds.

Therefore, it is important to identify the factors with the strongest impact on the fungal growth and toxicogenesis. Drought conditions recorded during the 2012 maize growing season, especially during the period from June to September, were associated with a decrease in the moisture content (average value was around 13\%) which resulted in unfavourable conditions for the growth of most fungal species, except certain Aspergillus species (Maslac, 2013). Lević et al. (2013b) reported that over the period 1967-2008 frequency of $A$. flavus in maize from Serbia varied from 2.9 to $16.0 \%$. However, in 2012 registered incidence of $A$. flavus was $95.3 \%$. Authors claimed that extremely stressful agrometeorological condition, over the period from flowering to waxy maturity of maize in 2012, was the main reason for such high incidence of $A$. flavus on maize. Furthermore, as a second factor causing intensive occurrence of $A$. flavus and AFs authors highlighted prevalence of European corn borer (ECB) (Ostrinia nubilalis). ECB influenced high damage and numerous injuries which were covered by visible olive-green powdery colonies, typical for A. flavus.

It could be noticed that weather conditions recorded during the 2012 maize growing season greatly influenced the high initial AFs contamination $(72 \%)$, which was further increased by the prolongation of storage period. During the observed 7-month storage period all factors that could contribute to maize quality deterioration were minimized (temperature and humidity control, pest control). Therefore, based on everything stated above it could be concluded that factors with the strongest influence on the high AFB1 incidence in the stored maize were severe initial infection and contamination of maize kernels before storage as well as the duration of storage period.

\section{CONCLUSIONS}

Based on the findings obtained in this study it can be suggested that maize kernels infected by fungi and contaminated with AFs should not be stored without previous application of some procedure for reduction of initial AFs contamination.

Considering the recorded changes in weather conditions in Serbia in recent years, given consequential economic losses and numerous negative impacts of AFs on human and animal health, a practicable and realizable strategy for reducing the risk of AFs contamination of maize should be developed. This strategy should be related to the implementation of monitoring program as well as some physical, chemical and/or biological procedures for AFs decontamination, with the main aim to avoid storage of contaminated maize. In order to prevent AFs presence, it is necessary to make every possible effort to improve agricultural practices (in particular, irrigation system), AFs control, and storage environments. 


\section{ACKNOWLEDGMENTS}

This study was supported by the Ministry of Education, Science and Technological Development of the Republic of Serbia, Projects No. III 46001 and TR 31029.

\section{REFERENCES}

1. Abbas, H.K., Williams, W.P., Windham, G.L., Pringle, H.C., Xie, W., Shier, T.W. (2002). Aflatoxin and fumonisin contamination of commercial corn (Zea mays) hybrids in Mississippi. Journal of Agriculture and Food Chemistry, 50, 5246-5254.

2. Castellari, C., Marcos Valle, F., Mutti, J., Cardoso, L., Bartosik, R. (2010). Toxigenic fungi in corn (maize) stored in hermetic plastic bags. Julius-Kühn-Archiv, 425, 501-504.

3. Cotty, P.J., Mellon, J.E. (2006). Ecology of aflatoxin producing fungi and biocontrol of aflatoxin contamination. Mycotoxin Research, 22, 110-117.

4. Ellis, W.O., Smith, J.P., Simpson, B.K., Oldham, J.H., Scott, P.M. (1991). Aflatoxins in food: occurrence, biosynthesis, effects on organisms, detection, and methods of control. Critical Reviews in Food Science and Nutrition, 30 (4), 403-439.

5. European Commission Regulation (2002). Commission Regulation 2002/32/EC of 7 May 2002 on undesirable substances in animal feed. Official Journal of the European Parliament, L 140, 10-21.

6. European Commission Regulation (2006a). Commission Regulation 401/2006 of 23 February 2006 laying down the methods of sampling and analysis for the official control of the levels of mycotoxins in foodstuffs. Official Journal of the European Union, $\mathrm{L}$ 70, 12-34.

7. European Commission Regulation (2006b). Commission Regulation 1881/2006 of 19 December 2006 setting maximum levels for certain contaminants in foodstuffs as regards Fusarium toxins in maize and maize products. Official Journal of the European Union, L 364, 5-18.

8. Garrido, C.E., Hernández Pezzani, C., Pacin, A. (2012). Mycotoxins occurrence in Argentina's maize (Zea mays L.), from 1999 to 2010. Food Control, 25, 650-665.

9. Harley, R.M. (1997). Mycotoxins in cereals. In Mycotoxins and environmental health. Ed. J.F.D. D'Mello, The Scottish Agricultural College, Edinburg, England, pp. 1-25.

10. Hell, K., Cardwell, K.F., Setamou, M., Poehling, H.M. (2000). The influence of storage practices on aflatoxin contamination in maize in four agroecological zones of Benin, West Africa. Journal of Stored Products Research, 36 (4), 365-382.

11. (IARC) International Agency for Research on Cancer. (2012). Chemical agents and related occupations, a review of human carcinogens in IARC monograph on the evaluation of carcinogenic risk to humans, Vol. 100F, World Health Organization, IARC, Lyon, France.

12. International Organization for Standardization (ISO) 21527-2 (2008). Microbiology of food and animal feeding stuffs - Horizontal method for the enumeration of yeasts and moulds - Part 2: Colony count technique in products with water activity less than or equal to 0,95 .

13. Juan, C., Zinedine, A., Molto, J.C., Idrissi, L., Manes, J. (2008). Aflatoxins levels in dried fruits and nuts from Rabat-Sale' area, Morocco. Food Control, 19, 849-853.
14. Kaaya, A.N., Kyamuhangire, W. (2006). The effect of storage time and agroecological zone on mould incidence and aflatoxin contamination of maize from traders in Uganda. International Journal of Food Microbiology, 110 (3), 217-223.

15. Karami-Osboo, R., Mirabolfathy, M., Kamran, R., Shetab-Boushehri, M. (2012). Aflatoxin B1 in maize harvested over 3 year in Iran. Food Control, 23, 271274.

16. Keller, L.A.M., Pereyra, M.G., Keller, K.M., Alonso, V.A., Oliveira, A.A., Almeida, T.X., Rosa, C.A.R. (2013). Fungal and mycotoxins contamination in corn silage: Monitoring risk before and after fermentation. Journal of Stored Products Research, 52, 42-47.

17. Kokić, B., Čabarkapa, I., Lević, J., Mandić, A., Matić, J., Ivanov, D. (2009). Screening of mycotoxins in animal feed from the region of Vojvodina. Proceedings for Natural Science, 117, 87-96.

18. Kos, J., Lević, J., Đuragić, O., Kokić, B., Miladinović, I. (2014). Occurrence and estimation of aflatoxin M1 exposure in milk in Serbia. Food Control, 38, 41-46.

19. Kos, J., Mastilović, J., Hajnal, J.E., Šarić, B. (2013). Natural occurrence of aflatoxins in maize harvested in Serbia during 2009-2012. Food Control, 34, 31-34.

20. Lević, J., Đuragić, O., Kos, J., Varga, J., Bagi, F. (2013a). The occurrence of aflatoxins in Serbia-from feed to food. The Second North and East European Congress on Food, Kiev, Ukraine, Proceedings, pp. 77.

21. Lević, J., Gošić-Dondo, S., Ivanović, D., Stanković, S., Krnjaja, V., Bočarov Stančić, A., Stepanić, A. (2013b). An outbreak of Aspergillus species in response to environmental conditions in Serbia. Pesticides and Phytomedicine, 28 (3), 167-179.

22. Luttfullah, G., Hussain, A. (2011). Studies on contamination level of aflatoxins in some dried fruits and nuts of Pakistan. Food Control, 22 (3), 426-429.

23. Maslac, T. (2013). Annual report on wheat, corn and barley for Serbia. US Department of Agriculture (USDA) Grain and Feed, pp. 1-17. (https://photos.state.gov/libraries/serbia/5/pdf/grainand-feed-annual-belgrade-serbia-3-22-2013.pdf).

24. Maslac, T. (2015). Grain and feed annual. US Department of Agriculture (USDA) Grain and Feed Animal, pp. 1-19.

(https://gain.fas.usda.gov/Recent\%20GAIN\%20Public ations/Grain\%20and\%20Feed\%20AnnualBelgrade S erbia 4-1-2015.pdf).

25. Matić, J., Mastilović, J., Čabarkapa, I., Mandić, A. (2009). Mycotoxins as a risk in the grain food. Matica srpska Proceedings for Natural Science, 117, 79-86.

26. Pitt, J.I., Hocking, A.D. (2009). Fungi and Food Spoilage. Springer Science - Business Media, New York, USA, pp. 3-9.

27. Pravilnik (1993). Pravilnik o mikrobiološkoj ispravnosti namirnica u prometu. Službeni list SRJ, 29/93.

28. Pravilnik (2010). Pravilnik o mikrobiološkim kriterijumima za hranu. Službeni glasnik RS, 72/10.

29. Pravilnik (2011). Pravilnik o maksimlano dozvoljenim količinama ostataka sredstava za zaštitu bilja u hrani i hrani za životinje i o hrani i hrani za životinje za koju se utvrđuju maksimalno dozvoljene količine ostataka sredstava za zaštitu bilja. Službeni glasnik RS, 28/11.

30. Pravilnik (2013). Pravilnik o maksimlano dozvoljenim količinama ostataka sredstava za zaštitu bilja u hrani i hrani za životinje i o hrani i hrani za životinje za koju se utvrđuju maksimalno dozvoljene količine ostataka sredstava za zaštitu bilja (2013). Službeni glasnik RS, 20/13.

31. Radović, V., Keković, Z. (2014). Development a comprehensive food safety system in Serbia-A Narrative Review Article. Iranian Journal of Public Health, 43 (7), 889-902. 
32. Samson, A.R., Hoekstra, S.E., Frisvad, C.J. (2004). Introduction to Food and Airborne Fungi. Centraalbureau vor Schimmelcultures, Utrecht, The Netherlands, pp. 1-389.

33. Santin, E. (2005). Mould growth and mycotoxin production. In Mycotoxin blue book. Ed D. Diaz, University Press, Nottingham, United Kingdom, pp. 225234.

34. SCS ISO/IEC 17025 (2006). General requirements for the competence of testing and calibration laboratories. ISO, Geneva, Switzerland.

35. STATISTICA (2011). Version 10.0, StatSoft, Inc., USA (www.statsoft.com).
36. Torović, Lj. (2015). Aflatoxin M1 in processed milk and infant formulae and corresponding exposure of adult population in Serbia in 2013-2014. Food Additives and Contaminants: Part B, 8 (4), 235-244.

37. Trung, T., Tabuc, C., Bailly, S., Querin, A., Guerre, P., Bailly, J. (2008). Fungal mycoflora and contamination of maize from Vietnam with aflatoxin B1 and fumonisin B1. World Mycotoxin Journal, 1 (1), 87-94.

38. Williams, J.H., Phillips, T.D., Jolly, P., Styles, J.K. Jolly, C.M., Aggarwal, D. (2004). Human aflatoxicosis in developing countries: a review of toxicology, exposure, potential health consequences, and interventions. American Journal of Clinical Nutrition, 80, $1106-1122$.

\title{
УТИЦАЈ ПЕРИОДА СКЛАДИШТЕЊА НА ПОЈАВУ И РАСПОДЕЛУ АФЛАТОКСИНА И ПЛЕСНИ У ЗРНУ КУКУРУЗА
}

Јована J. Кос ${ }^{\star 1}$, Елизабет П. Јанић Хајнал ${ }^{1}$, Љубиша Ћ. Шарић ${ }^{1}$, Драгана В. Плавшић ${ }^{1}$, Војислава П. Бурсић ${ }^{2}$, Горица Љ. Вуковић ${ }^{3}$, Јасмина М. Лазаревић

\author{
${ }^{1}$ Универзитет у Новом Саду, Научни институт за прехрамбене технологије у Новом Саду, 21000 \\ Нови Сад, Булевар цара Лазара 1, Србија \\ ${ }^{2}$ Универзитет у Новом Саду, Пољопривредни фракултет, 21000 Нови Сад, Трг Доситеја \\ Обрадовића 8, Србија \\ ${ }^{3}$ Универзитет у Београду, Институт за јавно здравље, 11000 Београд, Булевар деспота \\ Стефрана 54а, Србија
}

Сажетак: Основни циљеви овог рада били су да се испита утицај седмомесечног периода складиштења зрна кукуруза на појаву афлатоксина, као и да се испита расподела укупног броја плесни, врсте Aspergillus flavus и афрлатоксина Б1 у складиштеном кукурузу. Први део истраживања обухватио је 700 узорака кукуруза, који су сакупљани у периоду од октобра 2012. године до априла 2013. године. Пре складиштења зрна кукуруза у силосе, присуство афрлатоксина детектовано је у чак $72 \%$ узорака. Током складиштења кукуруза, у периоду од седам месеци, уочене су промене у проценту контаминираних узорака, као и у расподели концентрација афрлатоксина. Са продуживањем периода складиштења, проценат неконтаминираних узорака смањио се са $28 \%$ на $16 \%$, док се проценат узорака који је садржао афрлатоксине у концентрационом опсегу од $20 \mu \mathrm{g} / \mathrm{kg}$ до $50 \mu \mathrm{g} / \mathrm{kg}$ повећао током скла-диштења са $18 \%$ на $25 \%$. У другом делу истраживања, испитана су 32 узорка зрна кукуруза из четири различита силоса. Добијени резултати указали су да су плесни, A. flavus и афрлатоксин Б1 били неравномерно распоређени унутар сваког појединачног силоса, и да су према Данкановом тесту $($ < 0.05$)$ утврђене статистички значајне разлике за сваки испитивани параметар. Унутар сваког силоса утврђена је статистички значајна коорелација $(r=0.76$ at $p<0.05)$ између појаве микобиота A. flavus и концентрације афлатоксина Б1. Резул-тати добијени у овом раду, као и забележене климатске промене са којима се Република Србија суочава последњих година, указују на сталну потребу за унапређењем система у вези са превенцијом и контролом афрлатоксина у зрну кукуруза. Такође, добијени резултати могу бити од великог значаја за повећање практичних знања и вештина из наведене области, како у Србији, тако и у земљама из окружења. број плесни

Кључне речи: зрно кукуруза, складиштење, афрлатоксини, Aspergillus flavus, укупан

Received: 14 June 2018

Received in revised form: 7 August 2018

Accepted: 13 September 2018 